I. В. Ланова

\title{
ФОРМУВАННЯ НАВИЧОК ПРОФЕСІЙНОГО МОВЛЕННЯ СТУДЕНТІВ ТЕХНІЧНИХ СПЕЦАЛЬНОСТЕЙ
}

Ланова І. В. Формування навичок професійного мовлення студентів технічних спеціальностей.

У статті зазначено необхідність уведення курсу «Українська мова (за професійним спрямуванням)» у вищих навчальних закладах, його мету й основні завдання для формування в майбутніх фахівців умінь i навичок володіння українською літературною мовою у професійній діяльності, виокремлено основні блоки при його вивченні, а також основні складові процесу формування мовної особистості майбутнього фахівця.

Ключові слова: професійне мовлення, професійна комунікація, мовна підготовка, професійна культура, професійна діяльність, мовна особистість.

Лановая И. В. Формирование навыков профессиональной речи студентов технических специальностей.

В статье указано необходимость введения курса «Украинский язык (по профессиональному направлению)» в высших учебных заведениях, его цель и основные задачи для формирования у будущих специалистов умений и навыков владения украинским литературным языком в профессиональной деятельности,

(c) І. В. Ланова, 2016. 
выделены основные блоки при его изучении, а также основные составляющие процесса формирования языковой личности будущего специалиста.

Ключевые слова: профессиональная речь, профессиональная коммуникация, языковая подготовка, профессиональная культура, профессиональная деятельность, языковая личность.

Lanova I. V. Formation of professional speech skills of students of technical specialties. In the article the problem of higher education in the scientific and technical progress and restructuring of the socio-economic system in Ukraine. Outlined the severity of the situation on Ukrainian language in secondary schools and its use in all spheres of public life. It has been suggested scientists about the imperfections of language programs in disciplines shortage of skilled professionals, which ultimately leads to poor language training high school graduates, inability logically, consistently, coherently express their thoughts. Researchers are concerned about the lack of programs themes which help nurture national and universal tradition of rhetoric that are important personality traits - a full member of society. That's why higher education has gained urgency the problem of introducing new trends, content, methods, forms, preparing students for professional careers. Development of communicative culture of students - one of the urgent problems the teacher of high school. Ukrainian professional speech that is in its infancy, regimentation inherent features that define more cultural level of oral and written business communication and specificity of professional broadcasting is to serve the areas of industrial relations, communication needs between one profession. Because the course "Ukrainian language (for professional purposes)" in higher education not only eliminates gaps in learning the Ukrainian language in secondary schools in Ukraine, but also promotes proper professional training and intellectual level. He continued formation of national linguistic identity, broadens language competence of future specialist in the professional field, as the focus is shifting from the traditional task - assimilation of information about literary norms of the Ukrainian language - on the skills of professional communication, professional mastering features of language, the culture of the language. Shaping the future professionals skills and abilities fluency in Ukrainian literary language in the professional field, the course content is caused by a variety of tasks designed to ensure that students are properly used according to the language means and communicative needs as best guided in the speech process.

Key words: professional broadcasting, professional communication, language training, professional culture, professional activities, language identity.

Вища школа сьогодні - це освітня вершина для майбутніх фахівців, науковий фундамент для майбутніх учених, інтелектуальнокультурне середовище для зростання національної інтелігенції. Науковотехнічний прогрес, перебудова соціально-економічної та політичної системи в країні потребують від студента, майбутнього фахівця певної технічної галузі, не тільки знання свого фаху, а й високого рівня володіння професійним мовленням. Вихід української мови на 
міжнародну арену як мови суверенної держави, піднесення ії значення залежить від різноманітних факторів, зокрема від функціонування літературної форми національної мови у професійній сфері.

Підготувати висококваліфікованих фахівців, які вільно володіють державною мовою в різних їі формах - усній та писемній, завдання вищої школи. Але, на жаль, останнім часом виконати це завдання стає складніше. Гострота ситуації зумовлюється, по-перше, дебатами щодо необхідності використання російської мови як другої державної в усіх сферах суспільної діяльності поряд з українською мовою, по-друге, тим, що випускники середніх навчальних закладів (шкіл, гімназій, коледжів, ліцеїв тощо), за незначними винятками, маючи в атестатах добрі й відмінні оцінки з цього предмета, належних знань з української мови не мають. Вони не знають української літератури, українських письменників-класиків, їхніх творів, жанрів усної народної творчості, не мають елементарних навичок конспектування сприйнятого на слух тексту, мають низьку культуру мовлення, яке насичене сленговими словами, суржиком. Причини такого становища вбачають у недосконалих програмах цих дисциплін; у недостатній кількості годин, які виділяються на вивчення української мови та літератури; у дефіциті кваліфікованих фахівців.

Ця складна ситуація 3 українською мовою вимальовується останнім часом досить виразно. Якщо ми не будемо говорити про неї, значить не помічатимемо нагальної життєвої проблеми. Вона існуватиме до тих пір, поки не вгамуються пристрасті на найвищому державному рівні навколо питання про двомовність в Україні; поки середні навчальні заклади не перебудують системи навчання учнів української мови та літератури; поки державна мова в усіх сферах нашого суспільного життя не займе належне ій місце. Україномовне середовище сформується лише за умови практичної необхідності в українській мові [4].

Під час обміну інформацією виникає прямий обмін думками, поглядами, ідеями, з'являються різні форми взаємних стосунків, симпатії, антипатії, які становлять собою між особові стосунки. Отже,

(ㅇ.В. Ланова, 2016. 
слово - це робочий інструмент фахівця, мовлення - компонент його професійної майстерності. Від правильності, точності, доступності висловлювань залежить ефективність, результативність роботи майбутнього фахівця. Як стверджують дослідники, мовна підготовка випускників середніх шкіл часто не відповідає вимогам сьогодення. Особливі складності студенти відчувають у монологічних висловлюваннях - безсистемність, непослідовність, відсутність орієнтації на адресата. Без аргументації висловлених думок текст втрачає зв'язність, знижуються його комунікативні властивості [2].

А як бути зі становленням духовно-інтелектуальної особистості студентів через зростання типу моральної свідомості, всебічний гармонійний розвиток особистості, збереження універсальних загальнолюдських i національних традицій красномовства? На розвиток таких важливих якостей особистості - ознак повноцінного члена суспільства - часу в наших програмах зовсім не передбачено.

Отже, у сфері вищої освіти набула актуальності проблема впровадження нових напрямів, змісту, методів та форм підготовки студентів до професійної діяльності. Саме тому помітне місце на сучасному етапі реформування всіх ланок, розвиток вищої школи посідають процеси посилення інтенсивності й ролі інтеграції як синтетичного бачення досліджуваних феноменів, явищ, предметів у організації процесу навчання, без яких неможливо виховати та вивчити студентів усіх спеціальностей як досвідчених фахівців.

Однією з актуальних проблем, яку посталено перед викладачем вищої школи, є розвиток комунікативної культури студентів. Особливої уваги, на наш погляд, потребують чинні програми з української мови та культури мовлення. Адже повсюдно, замість того, щоб вивчати мову, вивчають граматику мови. Звичайно, добре коли економіст, програміст або технічний працівник знають правила орфографії, пунктуації, норми граматики. Але ці знання самі по собі неспроможні забезпечити належний рівень володіння мовою. Програма теж не передбачає завдань, які розвивали б мислення, уяву, емоційну сферу, зрештою, 
саме мовлення. Українське професійне мовлення перебуває на етапі становлення, унормування. Йому властиві ознаки, що визначають рівень культури усного й писемного ділового мовлення: правильність, комунікативна досконалість, аргументованість, доцільність, стислість, точність. А специфіка професійного мовлення полягає в обслуговуванні сфери виробничих відносин, потреб спілкування між представниками однієї професії. 3 практичних наслідків випливає, що добре знання мови фаху підвищує ефективність праці, допомагає краще орієнтуватися в складній професійній ситуаціі, оскільки кожна галузь науки має свої мовленнєві особливості, що виражаються в специфічній фаховій термінології, мовних кліше, професіоналізмах тощо.

Процес формування професійної культури мовлення відповідного фахівця складається 3 таких основних компонентів: 1) засвоєння професійної лексики й термінології фаху; 2) прищеплення студентам навичок роботи зі словниками, довідниками; 3) формування вмінь сприймання, відтворювання та створення фахових текстів різних видів $і$ стилів; 4) моделювання мовленнєвих ситуацій, які виникатимуть у майбутній професійній діяльності; 5) боротьба 3 мовленнєвою неохайністю в спілкуванні, уникнення типових порушень літературної мови в мовленнєвих стереотипах фахової галузі.

Формування високої культури мовлення є невід'ємною ознакою загальнолюдської культури. Зокрема процес формування мовної особистості майбутнього фахівця має такі основні складові: 1) становлення духовно-інтелектуальної особистості студента засобами красномовства; 2) формування загальної культури мовлення; 3) формування культури професійного мовлення. За умов інтенсивного розвитку науково-технічного прогресу, який постійно насичує професійне мовлення новими поняттями й термінами, основним критерієм визначення рівня культури професійного мовлення є ступінь оволодіння професійною термінологією та лексикою [6].

Отже, курс «Українська мова (за професійним спрямуванням)», уведений порівняно недавно у ВНЗ як навчальна дисципліна, є дуже 
потрібним, оскільки саме він певною мірою має ліквідувати, з одного боку, прогалини в навчанні української мови в середніх навчальних закладах України, а 3 другого, - сприяти підготовці фахівців належного професійного та інтелектуального рівня. Цей курс продовжує формування національно-мовної особистості, розширює мовну компетенцію майбутнього спеціаліста у професійній сфері. Акцент переноситься з традиційного завдання - засвоєння відомостей про літературні норми української мови - на формування навичок професійної комунікації, засвоєння особливостей фахової мови, на розвиток культури мови.

Мета курсу - формувати в майбутніх фахівців уміння й навички досконалого володіння українською літературною мовою в професійній сфері. Зміст курсу зумовлюється такими завданнями, спрямованими на те, щоб студенти правильно використовували мовні засоби відповідно до комунікативних потреб i якомога краще орієнтувалися в мовному процесі.

- оволодіти нормами сучасної української літературної мови, виробити навички правильного й доречного використання різноманітних мовних засобів залежно від сфери й мети висловлювання;

- набути навичок володіння термінологією майбутньої спеціальності;

- засвоїти відомості про призначення та структуру ділових документів і набути навичок самостійного складання різновидів ділових паперів;

- вільно користуватися різними функціональними стилями та їх підстилями в навчальній діяльності та професійному вжитку;

- розвивати комунікативні компетенції, потрібні в професійному спілкуванні [5].

При вивченні курсу «Українська мова (за професійним спрямуванням)» можна виокремити такі блоки:

- поглиблення знань студентів (учорашніх випускників) з української мови, здобутих ними в середніх навчальних закладах, а (ㄱ. В. Ланова, 2016. 
саме: з орфографії, орфоепії, лексикології, фразеології, словотворення, морфології, синтаксису, пунктуації, стилістики;

- піднесення культури їхнього усного та писемного мовлення;

- навчання професійної мови, зокрема робота 3 професійною термінологією;

- складання ділових документів різних типів;

- робота 3 текстами, яка допоможе виробити у студентів навички аналізувати, оцінювати, узагальнювати, коментувати й перекладати прочитане 3 однієї мови на іншу, правильно формулювати думки й доцільно використовувати відповідні мовні засоби залежно від сфери й мети висловлювань, забезпечує розвиток усного та писемного мовлення студентів;

- складання монологів, діалогів, полілогів на фахову тематику;

- написання анотації до запропонованої наукової статті;

- підготовка рефератів і коротких повідомлень (2-3хвилини) на різні теми, проведення ігор тощо;

- робота зі словниками, довідниками тощо [5].

Формування професійного мовлення студентів вищого технічного навчального закладу - вимога державного значення. Ефективність професійно зорієнтованого мовлення залежить не тільки від суті засвоєних студентами понять, термінів і правил, а й від вдалого добору дидактичного матеріалу, який сприяв би опануванню фахової лексики вільному спілкуванню на професійну тематику. Від того, наскільки вільно зможуть користуватися своїми професійномовленнєвими вміннями й навичками студенти, залежить їхня активність у виробничому та суспільному житті країни.

\section{Література}

1.Бутенко Л. Розвиток професійного мовлення майбутніх спеціалістів технічного профілю / Л. Бутенко // Дивослово. - 2014. - №1. - С. 17-18.

2. Бутенко Н. Ю. Комунікативні процеси у навчанні : [посібник] / Н. Ю. Бутенко, В. М. Приходько, Н. І. Федоренко. - К. : КНЕУ, 2004. - 334 с.

3. Культура фахового мовлення / за ред. Н Д. Бабич. - Чернівці : Книги XXI, 2011. $-572 \mathrm{c}$. 
4. Поповський А. М. Чинники та античинники культури сучасного українського мовлення / А. М. Поповський // Вивчаємо українську мову та літературу. - 2008. №13. - C. $2-3$.

5. Тоцька Н. Формування професійно зумовленого мовлення студентів технічного університету / Н. Тоцька // Дивослово. - 2009. - №9. - С.57-61.

6. Черемська О. Зміст і структура навчальної дисципліни «Українська мова» в економічних ВНЗ / О. Черемська, Г. Гайдамака, В. Жовтобрюх // Дивослово. - 2009. № 5. - C. 30-34.

Стаття надійшла до редакиії 24.11.2016 p. 